\title{
Condições de trabalho e saúde de uma associação de catadores de materiais recicláveis de Ceilândia, Brasil
}

artículo de investigación

\author{
Condiciones de trabajo y salud de una asociación de recolectores \\ de basura de Ceilândia, Brasil \\ research paper
}
Working conditions and health of an association of waste pickers of the Ceilândia, Brazil

\author{
Joaquim Pedro Ribeiro Vasconcelos ${ }^{1}$ \\ Instituto Federal de Educação, Ciência e Tecnologia \\ de Goiás e Universidade de Brasília \\ https://orcid.org/0000-0002-1399-0715
}

\section{Sílvia Maria Ferreira Guimarães² \\ Universidade de Brasília \\ (Di) https://orcid.org/0000-0002-2097-2355}

\section{Izabel Cristina Bruno Bacellar Zaneti ${ }^{3}$ \\ Universidade de Brasília \\ (Di) https://orcid.org/0000-0002-7484-1799}

\begin{abstract}
Resumo: Os catadores de materiais recicláveis estão inseridos em um contexto de vulnerabilidade. Diante disso, o objetivo principal deste estudo foi compreender as condições de trabalho e a situação de saúde dos catadores que trabalham em uma associação localizada na cidade de Ceilândia no Distrito Federal. Tratase de um estudo qualitativo, que utilizou a abordagem etnográfica. As técnicas aplicadas densamente foram as entrevistas semiestruturadas e conversas informais, além da observação participante do local de trabalho. Os resultados encontrados apontam que os catadores vivenciam contextos sociais complexos quanto a sua condição de trabalho, o que acarreta danos a sua saúde física e psicológica. A realidade do cotidiano mostra que o trabalho poderia ser desenvolvido com mais dignidade, se caso o poder público tivesse atenção direcionada para atender as necessidades deles. Ademais, estão totalmente desamparados, resistindo aos contextos de pobreza, as situações cotidianas de desigualdade de gênero, aos estereótipos da ocupação e ao desemprego. Os contextos de vida, trabalho e saúde dos catadores apresentam particularidades específicas inerentes ao ser catador na sociedade capitalista. Por essa razão, a sobrevivência em meio as doenças e aos agravos à saúde produzidos naturalmente pelo cotidiano da ocupação, somadas a isso as condições de trabalho totalmente precárias, fazem do ser catador trabalhadores resistentes as desigualdades, principalmente a mulher catadora.
\end{abstract}

Palavras-Chave: Catadores de materiais recicláveis; Condição de social; Saúde ambiental

Recibido: 26/03/2019 | Aceptado: 27/01/2020 | Disponible en línea: 05/06/2020

Como citar este artigo: Vasconcelos, J. P. R., Guimarães, S. M. F. \& Zaneti, I. C. B. B. (2020). Condições de trabalho e saúde de uma associação de catadores de materiais recicláveis de Ceilândia/Distrito Federal. Jangwa Pana, 19 (3), 364 - 389. DOI: https://doi.org/10.21676/16574923.3516

\footnotetext{
1. End. Eletrônico: vasconcelosjpr@gmail.com.

${ }^{2}$ End. Eletrônico: silviag@unb.br.

${ }^{3}$ End. Eletrônico: izabel.zaneti@yahoo.com.
} 
Resumen: Los trabajadores recolectores de basura se insertan en un contexto de vulnerabilidad. Ante esto, el objetivo principal de este estudio fue comprender las condiciones de trabajo y la situación de salud de los recolectores de basura que trabajan en una asociación ubicada en la ciudad de Ceilândia en el Distrito Federal. Este es un estudio cualitativo que utilizó el enfoque etnográfico. Las técnicas densamente aplicadas fueron entrevistas semiestructuradas y conversaciones informales, así como la observación participante del lugar de trabajo. Los resultados muestran que los recolectores experimentan contextos sociales complejos con respecto a su condición de trabajo, lo que causa daños a su salud física y psicológica. La realidad de la vida diaria muestra que el trabajo podría desarrollarse con más dignidad, si el poder público hubiera centrado la atención para satisfacer las necesidades de estos sujetos. Además, están totalmente indefensos, resistiendo los contextos de pobreza, las situaciones cotidianas de desigualdad de género, los estereotipos de ocupación y desempleo. Los contextos de vida, trabajo y salud de los recolectores tienen peculiaridades específicas inherentes a ser recolectores de basura en la sociedad capitalista. Por esta razón, la supervivencia en medio de las enfermedades y problemas de salud producidos naturalmente por la vida cotidiana de la ocupación, sumado a esto las condiciones de trabajo totalmente precarias, hacen que los recolectores sean resistentes a las desigualdades, especialmente a las mujeres.

Palabras claves: Recolectores de basura; Condiciones sociales; Salud ambiental

\begin{abstract}
Waste pickers are placed in a context of vulnerability. Therefore, the main objective of this study was to understand the working conditions and the health situation of waste pickers who work in an association located in the city of Ceilândia in the Federal District. This is a qualitative study that used the ethnographic approach. The densely applied techniques were semi-structured interviews and informal conversations, as well as participant observation of the workplace. The results show that the pickers experience complex social contexts regarding their working condition, which causes damage to their physical and psychological health. The reality of daily life shows that the work could be developed with more dignity, if the public power had focused attention to meet the needs of these subjects. Moreover, they are totally helpless, resisting the contexts of poverty, the daily situations of gender inequality, the stereotypes of occupation and unemployment. The life, work and health contexts of waste pickers have specific peculiarities inherent in being waste pickers in capitalist society. For this reason, to survive in the midst of the diseases and health problems naturally produced by the daily life of the occupation, added to this the totally precarious working conditions, make being scavengers resistant subjects to inequalities, especially women scavengers.
\end{abstract}

Keywords: Waste pickers; Social conditions; Environmental health

\title{
Introdução
}

Este artigo apresenta um estudo qualitativo do contexto de trabalho e saúde de catadores de materiais recicláveis de uma Associação que atua em uma Usina de Reciclagem e Compostagem de Resíduos Sólidos, localizada na Região Administrativa de Ceilândia, "periferia" do Distrito Federal - DF e cidade mais populosa do território candango. Como uma "periferia", Ceilândia é estigmatizada na imprensa e pelos moradores de outras regiões do DF como um local violento e fonte de problemas sociais. No entanto, como será abordado neste estudo, em Ceilândia vivem cidadãos atuantes e há vidas intensas que contradizem todos os estereótipos.

O crescimento da classe trabalhadora de catadores associados, ocasionado principalmente pelo desemprego, aponta para necessidade de atenção governamental para construção ou aperfeiçoamento das políticas públicas voltadas a sustentabilidade e à saúde desses trabalhadores, haja vista que a realidade empírica transforma as desigualdades sociais em desigualdades de saúde (Leandro, 2011). Os trabalhadores ficam ainda mais sujeitos pois exercem trabalhos duros, desgastantes, mal pagos e desvalorizados, de sobremaneira os migrantes e outras minorias similares (Leandro, 2011). Assim, o grupo de catadores enquadra-se nessa realidade. As políticas públicas devem ser organizadas para contemplar as suas reais necessidades, quanto à condição de alimentação, habitação, educação, renda, ambiente, trabalho, emprego, lazer e acesso aos serviços de saúde. 
Este tipo de ocupação é exercido por profissionais que se organizam de forma autônoma ou em cooperativas e associações (Vasconcelos, Guimarães, \& Zaneti, 2018). Atualmente, as usinas e galpões de reciclagem estão sendo capazes de absorverem a mão-de-obra que vivia dos lixões e das ruas. As usinas de reciclagem surgem como uma alternativa sustentável para a destinação do lixo urbano, o que rotineiramente era e ainda é realizado no espaço dos lixões em algumas regiões brasileiras.

Do mesmo modo, esse processo foi impulsionado no país pela Lei n. 12.305 (2010) que institui a Política Nacional de Resíduos Sólidos - PNRS, a qual estabeleceu obrigatoriedade de implantação de Planos de Gerenciamento de Resíduos Sólidos em todos os municípios brasileiros e no DF, com programas de coleta seletiva e inclusão dos catadores, prevendo a extinção dos lixões até o ano de 2014, embora esse prazo tenha sido prorrogado algumas vezes. E inclusive no DF após o fechamento do lixão da Estrutural, o maior lixão da América Latina (Froes, 2016), ocorrido no ano de 2018 houve a criação de novos galpões de reciclagem para abarcarem os trabalhadores do lixão. Todavia o contexto dos catadores nos lixões e nas ruas se diferem da realidade socioambiental dos catadores inseridos nas associações.

Dessa maneira, esse processo de transformação do ambiente de trabalho da catação foi intensificado pelo poder público, embora requer maior atenção governamental no sentido da proteção social para os catadores. A mudança acaba permitindo uma venda em maior escala dos materiais recicláveis. Ao mesmo tempo que a transformação permite maior produtividade do catador, os seus corpos são violados, ainda são submetidos a situações provocadoras de adoecimento. A transformação para a organização dos catadores em associações ou cooperativas apresenta um cenário que precisa de atenção dos gestores públicos para compreensão das necessidades relacionadas ao trabalho e a vida desses trabalhadores. Nesse sentido, a pesquisa social em saúde tem sua importância na compreensão de quem são esses catadores, que trabalham de forma autônoma, mas associados, revelando principalmente a singularidade da sua atividade laboral.

Ademais, os catadores estão inseridos em um contexto marcado pela desigualdade social, racial e gênero, sendo esses fenômenos capazes de exercer influência negativa na vida desses trabalhadores, logo também afeta à saúde. Segundo a autora Leandro (2011) a forma como as desigualdades são produzidas socialmente se exprimem no corpo, ou seja, com o modo como o social se inscreve no biológico. Assim Leandro (2011) reconhece as desigualdades sociais como igualmente desigualdades perante a saúde, a doença, a vida e a morte. Logo as desigualdades sociais, também são analisadas aqui igualmente como desigualdade de saúde.

Os catadores resistem a esse processo de exclusão cotidianamente, em contrapartida são fundamentais para garantia da cadeia de reciclagem no país (Dall’Agnol \& Fernandes, 2007). Devido a importância da atividade laboral para a reciclagem, a realidade estudada sinaliza que esses trabalhadores necessitam de políticas públicas sociais por parte do governo e reconhecimento da sociedade da importância da atividade do catador. Nesse sentido, o cotidiano de trabalho dos catadores de materiais recicláveis associados apresenta riscos à saúde e padrões de adoecimento peculiares (Vasconcelos et al., 2018; Dall’Agnol \& Fernandes, 2007).

Os catadores são trabalhadores que estão expostos a riscos à saúde e que precisam ter seus direitos sociais garantidos enquanto trabalhadores e cidadãos (Vasconcelos et al., 
2018). É um grupo social que está inserido em situações de precarização da vida devido a posição que ocupa na sociedade e aos fatores relacionados ao trabalho. Segundo Júnior, Ramos, Alves, Forcellini e Graciolli (2013) algumas patologias e sintomas estão relacionadas ao trabalho de catação como: verminoses, infecção intestinal, gripe, leptospirose, dengue, meningite, dor de cabeça, dor de dente, febre, alergia e náusea, sendo que a possibilidade de cura rápida determina a importância da doença para os catadores. Estudo realizado por Dall'Agnol e Fernandes (2007) aponta que as morbidades mais frequentes advindas do contato humano direto ou indireto com os resíduos sólidos e recicláveis são as doenças diarreicas, diretamente relacionadas à lavagem das mãos, e aquelas transmitidas por vetores biológicos e mecânicos.

O trabalho é uma das principais fontes de satisfação humana, pois proporciona a autorrealização, a manutenção de relações interpessoais e a própria sobrevivência. Mas, o trabalho, também, pode ser uma fonte de adoecimento, quando o profissional não dispõe de instrumentos suficientes para se proteger dos fatores de risco à saúde (Goto, Souza, \& Júnior, 2009). E também quando se trata de um trabalho explorado e alienante. Para Mandel (1982), o Estado serve para manter a classe operária inerte contra o sistema capitalista, assim permanece a alienação do trabalhador que identifica as causas da sua ocupação como naturais e flexíveis.

Os riscos à saúde pública relacionados aos resíduos sólidos decorrem da interação de uma variedade de fatores que inclui aspectos sociais, ambientais, ocupacionais e de consumo, entre outros (Siqueira \& Moraes, 2009). O elemento da dimensão social caracteriza-se pelo próprio fato dos padrões de desenvolvimento adotados, após o processo histórico da industrialização, favorecerem a degradação ambiental por meio da exploração predatória dos recursos naturais e o aumento da poluição, deixando em segundo plano na agenda política a proteção e a conservação dos recursos naturais. Os aspectos ambientais estão relacionados, principalmente a transmissão de doenças provocadas pela ação dos vetores encontrados no lixo, além disso os resíduos podem contaminar o ar, a água e o solo. Também envolve a questão do tratamento adequado para o lixo urbano, através dos planos de gerenciamento dos resíduos sólidos ou a coleta seletiva nos ambientes domésticos e nas instituições.

Paralelamente, os aspectos ocupacionais estão relacionados a própria atividade do catador, haja vista o seu surgimento a partir de uma massa de excluídos, que passaram a se "beneficiar" da geração excessiva dos produtos, tendo nessa atividade o seu meio de sobrevivência e a obtenção de renda (Siqueira \& Moraes, 2009). Embora a realidade social dos catadores estudada mostra que o trabalho produz doenças e os trabalhadores vivem à margem da sociedade, deixando arreigado nessa atividade as marcas do preconceito. Os fatores referentes ao consumo baseiam-se na premissa dos padrões insustentáveis de consumo e produção que provocam, especialmente o agravamento da pobreza. Ainda a exploração dos recursos naturais e humanos, instituindo a mercantilização da vida.

Esse quadro torna-se complexo, no contexto dos catadores, devido ao fato de não apresentarem suporte socioeconômico. Todavia, para além do trabalho, apresentam condições de vida desfavoráveis, havendo um acumulado de fenômenos e fatos que vão influenciar negativamente no seu contexto de saúde, a partir de uma leitura das ciências sociais, como: o estigma da ocupação, as situações precárias de trabalho, as violências, a dificuldade no acesso aos serviços de saúde pública, o racismo e a desigualdade de 
gênero. Assim sendo, as vidas precarizadas e vulnerabilizadas dessas pessoas são reflexos das desigualdades estruturantes produzidas na sociedade.

Diante desse cenário problemático que envolve os resíduos sólidos nos centros urbanos, tendo como compreensão a vida e o trabalho dos catadores, atores principais no elo da cadeia da reciclagem, que este estudo imergiu.

\section{Materiais e métodos}

\section{A Cidade de Ceilândia}

Segundo dados da Pesquisa Distrital Por Amostra de Domicílios - Ceilândia - PDAD, realizada pela Companhia de Planejamento do Distrito Federal - CODEPLAN (2015), a cidade da Ceilândia surgiu em decorrência da Campanha de Erradicação das Invasões CEI, que foi o primeiro projeto de erradicação de favelas realizado no DF pelo governo local. As remoções para a nova cidade foram iniciadas em 27 de março de 1971, estabelecendo a data de sua fundação a partir da transferência de, aproximadamente 80.000 moradores das favelas da Vila do IAPI, Vila Tenório, Vila Esperança, Vila Bernardo Sayão e Morro do Querosene, destacando que havia somente o cerrado, a cidade não tinha nenhuma infraestrutura.

Entretanto, devido ao crescimento desordenado da cidade e, principalmente, da migração de pessoas, principalmente do Nordeste do Brasil, que buscavam melhores condições de vida na Capital Federal - Brasília, Ceilândia se tornou a cidade mais populosa do DF. O seu início foi marcado pela organização da população na luta por melhores condições de vida, assim, fazendo com que fosse conquistado o acesso às políticas públicas como saneamento, energia, telefonia e educação. A Usina de Reciclagem e Compostagem de Resíduos Sólidos espaço onde foi desenvolvido este estudo está localizada no bairro P Sul, sendo que os catadores entrevistados participantes residem na QNR. A QNR é um território constituído por pessoas de camadas populares, no qual a maioria dos seus habitantes conseguiram a casa própria por meio de programas habitacionais do governo local. Além disso, a região possui problemas de infraestrutura, como a falta de iluminação pública, o asfalto inadequado de baixa qualidade, o sistema de captação de água da chuva ineficiente, ausência de espaços de lazer e a limpeza urbana precária. Ainda assim, essa periferia tem as marcas da violência, confirmada pelos assassinatos, os espaços destinados ao tráfico de drogas e os roubos/furtos na região.

\section{A área do estudo}

Este estudo analisa a realidade cotidiana, no que se relaciona ao contexto do trabalho e saúde, de uma associação de catadores. $\mathrm{Na}$ área do estudo trabalhavam duas associações de catadores, distintas entre si quanto ao seu processo produtivo. No local, funcionava também uma empresa responsável pelo recolhimento dos rejeitos urbanos nas residências do DF e uma sede administrativa do Serviço de Limpeza Urbana - SLU. Todas essas organizações e instituições funcionavam em um território de responsabilidade do Governo, principalmente no horário diurno. 


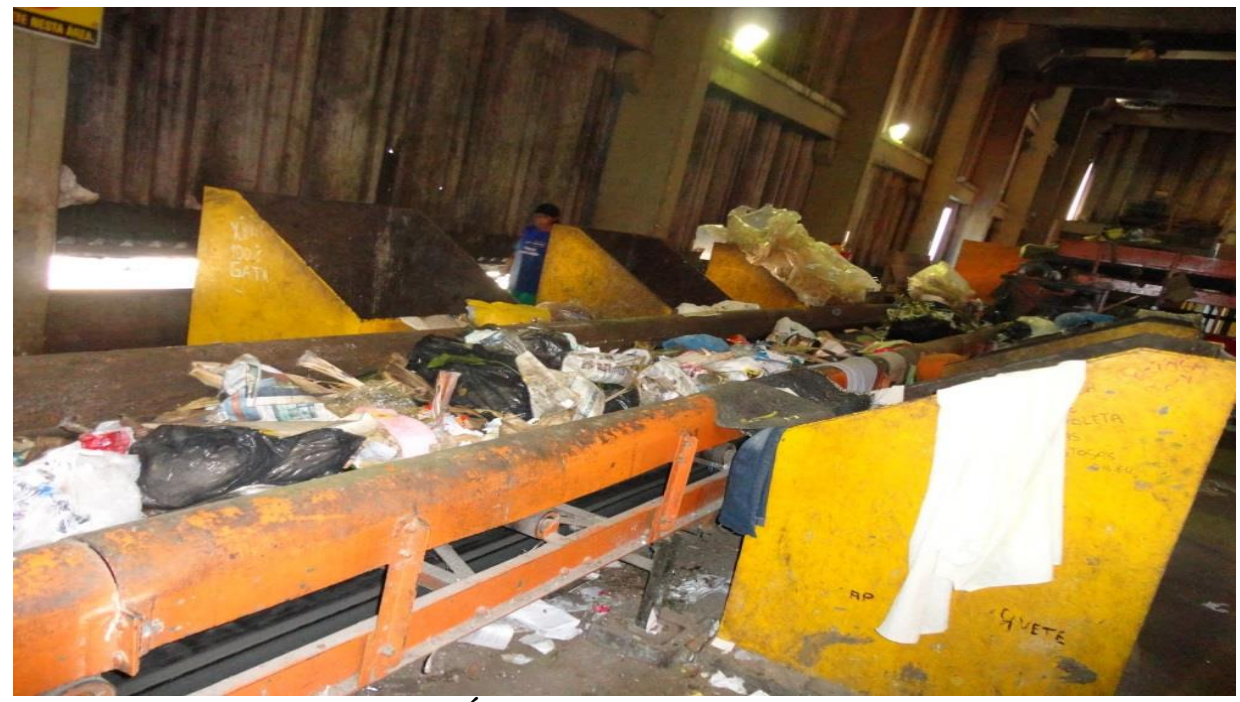

Figura 1. Área interna de esteiras da Usina.

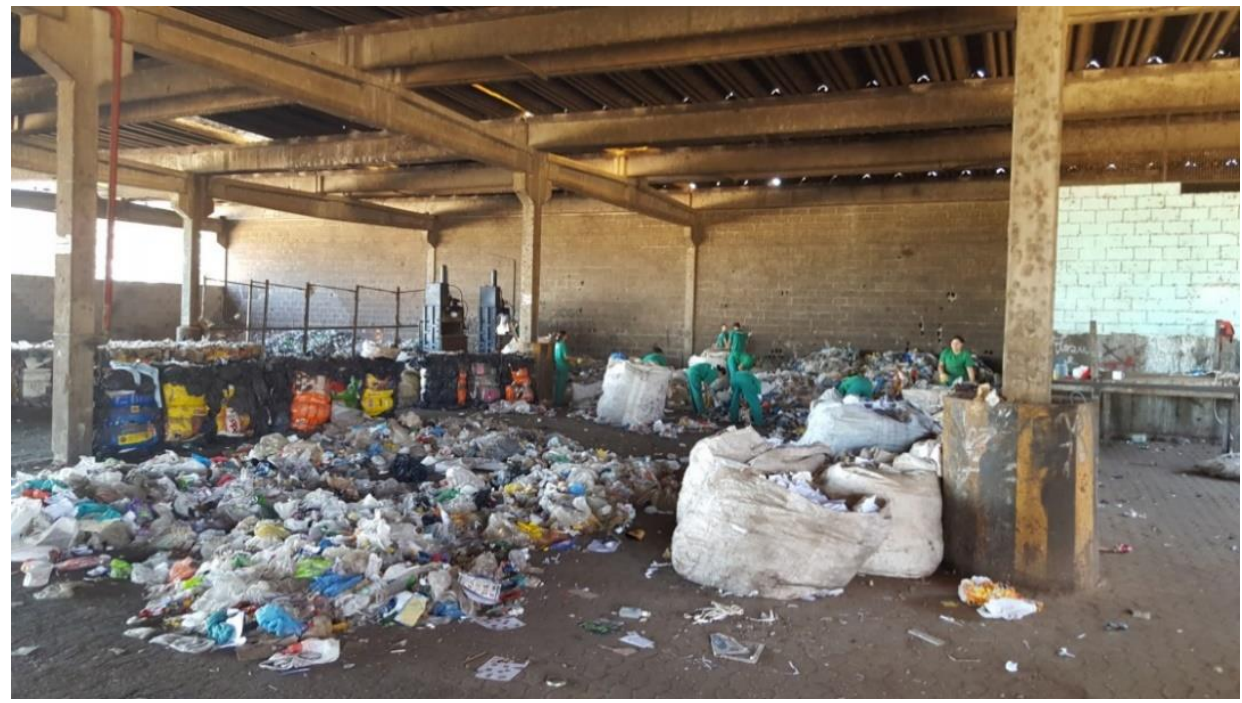

Figura 2. Galpão de triagem de materiais recicláveis da Usina.

A dinâmica de trabalho das associações de catadores de materiais recicláveis está baseada na responsabilidade de separação do lixo reciclável e na limpeza dele para posteriormente virar mercadoria. Há uma crescente especialização e divisão do processo de trabalho entre grupos de catadores e suas associações nas usinas e galpões industriais com foco no aumento da produtividade das associações. Essa organização do trabalho da cata foi provocada pela transição do catador que trabalhava nas ruas ou nos lixões para catadores que agora desenvolvem suas atividades em espaços públicos ou particulares de triagem de materiais, tendo significado marcante para a constituição dessa ocupação.

No que se refere à organização, as unidades de triagem organizam os operadores por meio da criação de associações, que são constituídas juridicamente, dispondo de autonomia administrativa e operando mediante estatutos e regimentos internos específicos, em que se definem suas normas de gestão e funcionamento. A respeito da rotina de produção no galpão, o trabalho começa com a chegada do caminhão que despeja os resíduos no local 
adequado em cada unidade, os materiais recebidos são classificados, separados, armazenados, para depois serem comercializados.

No que tange ao objeto de trabalho com os resíduos, nos galpões, este material já selecionado, será triado prensado, pesado e vendido e voltará para o ciclo produtivo, para serem reaproveitados e reciclados novamente nas indústrias (Zaneti, 2006). Através dessa organização, segundo a Classificação Brasileira de Ocupações - CBO, definida pelo Ministério do Trabalho e Emprego - MTE (2013), surgem nas associações especializações do trabalho que tendem a aumentar o número de funções de trabalho, como as de selecionador, triador, enfardador de sucatas e operador de prensa.

Nessa associação de catadores, havia também o turno noturno, onde o trabalho acontecia no contexto da usina. Assim, nas esteiras internas da Usina os catadores separavam e coletavam os materiais recicláveis. No mesmo local funcionava outra associação de catadores que também utilizava o espaço da usina para separação do material reciclado, mas essa associação não trabalhava no período noturno e não participou deste estudo.

Assim o trabalho nesta Usina pública era dividido entre duas associações, uma de catadores que atuavam no turno diurno e outra no turno noturno. Os catadores trabalhavam nas esteiras que ficavam dentro da Usina, coletando e separando os materiais recicláveis para que, no dia seguinte, os catadores do turno diurno exercessem o trabalho de triagem e separação manual no galpão de materiais recicláveis.

Após a separação dos materiais fruto do trabalho inicial dos catadores na Usina, no turno noturno, esses materiais eram destinados ao galpão de triagem de materiais recicláveis. Nesse galpão tinha os catadores e pessoas que trabalhavam para um atravessador, dividindo os espaços entre si para que não ocorresse a mistura dos materiais.

As atividades de ambos trabalhadores são a separação, a limpeza, a prensa e a venda dos resíduos: sedas, pets, latinhas, cobre e papéis. Esses catadores do galpão de triagem fazem parte grupo de pessoas com quem interagimos. Não foi possível imergir no turno de trabalho noturno, principalmente pelas dificuldades do pesquisador em conseguir autorização.

\section{Método, procedimentos e técnicas de investigação}

Trata-se de uma pesquisa qualitativa. Essa metodologia trabalha com as pessoas e o seu modo de atuação em determinado contexto social (Minayo, 2010), no caso deste estudo, o foco é a realidade cotidiana de vida dos catadores de materiais recicláveis, procurando aprofundar na complexidade dos fenômenos e fatos sociais que mostram a singularidade das condições de trabalho e da situação de saúde desse grupo social. O grupo de catadores de materiais recicláveis que é abordado e compreendido neste trabalho são aqueles catadores organizados coletivamente em associações/cooperativas, pois suas atividades têm forte dependência da atuação do Estado. Segundo Creswell (2010), em todo processo de pesquisa qualitativa, o pesquisador mantém um foco na aprendizagem do significado que os participantes dão aos problemas ou as questões e não ao significado que os pesquisadores trazem para a pesquisa ou o que os autores expressam na literatura.

Dessa maneira, os procedimentos de investigação do problema e as técnicas pertinentes a esses procedimentos tiveram como base os princípios do fazer etnográfico: o olhar, o ouvir e o escrever. Segundo Oliveira (1996), o trabalho de campo com a abordagem 
etnográfica contempla esses três momentos. O olhar e o ouvir cumprem a função de coleta de dados, enquanto o escrever faz parte do momento de análise e interpretação dos dados obtidos em campo.

As técnicas usadas no trabalho de campo foram baseadas em entrevistas semiestruturadas e um diário de campo para anotações de vários fatos que ocorreram no ambiente da pesquisa, assim como as impressões pessoais do pesquisador. Assim, a observação participante do local de trabalho dos catadores foi complementada com entrevistas semiestruturadas e anotações provenientes das conversas informais. Todos esses momentos de interação com os trabalhadores e com o ambiente tiveram vínculos estreitos. Antes de iniciar a pesquisa, o pesquisador foi ao local de trabalho dos catadores onde foi possível manter estreita conversa com a presidente da associação e outro encarregado administrativo para negociação do campo. Com isso foi possível conhecer o ambiente e o contexto do trabalho de catação, sendo possível também neste momento criar uma relação de confiança entre trabalhadores e pesquisadores.

O trabalho de campo foi realizado entre os meses de outubro de 2015 a fevereiro de 2016. Foram, aproximadamente, cinco meses de imersão no campo, compreendidos desde a etapa de negociação até o encerramento das entrevistas, utilizando o critério de saturação de Deslandes (2012). As visitas aconteciam pelo menos uma vez por semana, em algumas semanas chegavam a ser duas visitas. Neste período, foram realizadas as entrevistas com os catadores de materiais recicláveis, os participantes eram convidados na medida que aceitavam o convite, esses indicavam outros colegas para participarem, tornando o processo cíclico. Principalmente, as mulheres se disponibilizaram a participar.

A primeira catadora entrevistada foi indicada pela presidente da associação. Durante esse processo, houveram aqueles que não aceitaram ou quiseram participar das entrevistas e quando isso acontecia o entrevistado indicava outra pessoa. Embora esses que não aceitaram participar da entrevista, em outros momentos foram atores sociais importantes, seja na sua atuação no ambiente de trabalho ou nas conversas informais com os pesquisadores.

Durante o momento das entrevistas os pesquisadores agendavam com o participante o próximo encontro para continuidade da entrevista, escolhendo o melhor horário, haja vista que os participantes estavam em horário de trabalho, assim as entrevistas individuais tiveram duração em torno de 20 a 40 minutos. O próprio contexto de trabalho da associação, incluindo o espaço destinado para descanso e alimentação, foram os locais privilegiados do trabalho de campo, onde se deram os primeiros encontros e as interações com os interlocutores. Destaca-se que houveram momentos que foi necessário remarcálas devido à dinâmica do trabalho em determinado dia, ao não comparecimento no trabalho e, também, à não vontade do participante de participar do diálogo no dia e horário marcados.

As temáticas tratadas e que foram sendo elaboradas ao longo do campo se dividem em questões relacionadas a realidade vivida pelos participantes, no que tange os aspectos relacionados à situação cotidiana sobre as condições de trabalho, o sentido do trabalho de catador, a vida e saúde. Não foram publicizadas imagens e nem gravações das pessoas entrevistadas e, quando os entrevistados permitiram, foram feitas gravações das entrevistas a fim de sistematizar as informações mais significativas, após foram feitas as 
transcrições das mesmas, analisando-as a partir da unidade de significados de Minayo e Gomes (2012).

Ressalta-se ainda que de modo a assegurar o anonimato dos entrevistados foram utilizados, ao final dos trechos das entrevistas, os termos "catador" ou "catadora" e a idade dos trabalhadores, assim como os nomes pessoais e de familiares citados nos relatos foram modificados para nomes fictícios. E para os indivíduos do mesmo gênero que apresentaram a mesma idade foi utilizado um número entre parênteses logo após os termos "catador" ou "catadora" para a diferenciação dos entrevistados.

Por fim, respeitando as questões éticas, esta pesquisa foi aprovada pelo número do parecer 783.155 submetida ao Comitê de Ética em Pesquisa do Instituto de Ciências Humanas da Universidade de Brasília.

\section{Resultados e discussão}

\section{Dos aspectos populacionais dos catadores}

A interação com os participantes e o ambiente se deram durante o turno de trabalho matutino no galpão de triagem dos materiais recicláveis, tendo como universo quinze catadores, sendo que dez aceitaram participar das entrevistas, 4 homens e 6 mulheres. A faixa etária foi diversificada, com indivíduos com idade entre dezoito a trinta e seis anos. A maioria se encontra na faixa etária jovem - com idade entre os 18 e 24 anos.

Em relação à cor da pele, a maioria dos entrevistados se consideraram pardos, sendo que um se autodeclarou moreno, nenhum se declarou branco. No que se refere à escolaridade um concluiu o ensino médio e segue com formação em cursos profissionalizantes na área da informática; uma terminou os estudos na educação de jovens e adultos e sonha fazer o curso superior de pedagogia; e os demais estudaram até o ensino fundamental. Esse cenário revela que a baixa escolaridade é uma realidade do grupo entrevistado, assim como encontrado no contexto de outros estudos com catadores (Almeida, Elias, Magalhães \& Vieira, 2009; Gonçalves, Malafaia, Castro \& Veiga, 2012; Santos, Jesus, Mattos, Alves, Vicente \& Jesus, 2012).

Em relação à moradia, a maioria residia em barracos alugados, sendo que a casa da sogra e a casa da mãe também constituíam como locais de moradia. Duas das catadoras possuíam casa própria: uma conseguiu devido à luta incansável por moradia, característico do DF, enfrentando resistência nas invasões no entorno da área central de Brasília, a capital do Brasil. Uma inclusive sofreu junto com sua família violência policial e a outra adquiriu devido o programa governamental "Programa Minha Casa Minha Vida", estando localizada a sua residência no entorno do DF, na cidade de Águas Lindas de Goiás.

Todos os catadores moravam na região da QNR em Ceilândia, exceto uma catadora. Esse bairro possui rede elétrica, rede de esgoto, asfalto e água tratada, embora seja uma favela possui boa infraestrutura. Entretanto, a iluminação pública das ruas foi apontada como péssima pelos entrevistados. Eles destacaram as excessivas reclamações referentes à violência urbana (roubos, brigas e homicídios) e à falta de lazer.

A renda oriunda do trabalho de catação era de acordo com a produção, estava entre 1.000 a 1.500 reais por mês. Parte significativa dos entrevistados evidenciaram que com a renda da catação conseguiam atender as suas necessidades, sendo que dois disseram mais ou 
menos. A necessidade de trabalhar em outro local para aumentar a renda não era realidade desses catadores. Uma catadora afirmou que recebia auxílio governamental financeiro do "Programa Bolsa Família" e um catador realizava "bicos" arrumando computadores, como relatado abaixo:

Faço só na área de informática, né, porque eu conheço bastante. Aí, ás vezes, eu faço algum trabalho relacionado à área de informática, mas é muito pouco, é muito raro. (CATADOR, 27 anos).

Os catadores eram predominantemente da região Nordeste - dos municípios dos Estados da Bahia, do Piauí e do Maranhão - tendo apenas uma catadora que nasceu em Brasília. O Nordeste é a segunda região mais populosa do Brasil e ocupa uma extensa área territorial. Em relação ao seu povo da região do sertão é comum eles fugirem da seca, miséria e falta de perspectivas de vida. Assim procuram melhores condições de vida nas cidades urbanas do Nordeste ou em outras regiões do Brasil, mas como não possuem recursos acabam vivendo em bairros desprovidos de infraestrutura adequada e acabam marginalizados. Os catadores estão incluídos nessa realidade.

Todos chegaram à Brasília ainda crianças com os seus familiares - como tios, pais, irmãos e mães - em busca de melhores condições de vida e, principalmente, de trabalho. Todos trabalharam quando menores de idade, as mulheres, geralmente, em casas de famílias ou parentes, e os homens em serviços braçais. Os entrevistados tinham como referência no DF e entorno alguns familiares que aqui já habitavam, o que facilitou a vinda para a capital federal, como demonstra o relato a seguir:

Tenho irmã que trabalha aqui na Associação, a maioria aqui são meus primos. Aí aqui em Brasília, eu achei mais recurso de vida para trabalhar, aí eu vim tipo tentar a vida, né, trabalhar para conseguir alguma coisa. (CATADOR, 18 anos).

A religião mais predominante entre os entrevistados foi a evangélica (7), sendo o restante da religião católica (3). Os catadores evangélicos frequentavam cotidianamente a igreja e possuíam relações interpessoais com os seus colegas fiéis, frequentando os cultos praticamente todos os dias. Os católicos procuravam a igreja às vezes, não tendo grande frequência.

Existia uma variedade no tempo que trabalhavam como catadores, desde 20 anos até apenas 4 meses, mas a maioria possui entre 4 e 6 anos. Nas suas singularidades com o trabalho, o fato de serem associados trazia qualidade, devido às condições físicas do ambiente, e ressaltaram a sociabilidade com os colegas de trabalho como elemento positivo da lida cotidiana. Na rotina do trabalho, os catadores conversavam e interagiam entre si e alguns se tornam amigos e, com isso, as horas no galpão de triagem, segundo os entrevistados, passavam mais rapidamente. Nenhum catador relatou ter trabalhado em lixões antes da Associação.

A entrevistada mais experiente trabalhava como catadora há 20 anos, anteriormente estava nas ruas das cidades do DF, empurrando carrinho e coletando materiais nas lixeiras das casas, e, também, afirmou ter sido pedinte nas ruas do DF. Enfatizou que houve uma melhora significativa em sua vida depois que começou a trabalhar como associada: 
Muita diferença, principalmente, o benefício, né, porque na cooperativa tem benefício né? E também, é assim, é mais divulgado né? Nós na rua não "era" divulgado e na cooperativa é mais divulgado [...] Aqui trabalha em grupo, muita vantagem mesmo, nós vamos conversando [...] Aqui uma ajuda às outras, na hora que uma tá no perrengue e a outra tá mais folgada a gente ajuda. Tem também a presidente, né, que dar muito apoio pra gente, apoio moral e financeiro também. Quando ela pode ela ajuda mesmo, a gente sabe, então não tenho o que falar não. Vixe, melhorou foi muito, muito mesmo. (CATADORA, 36 anos).

Apenas um catador relatou já ter tido emprego com carteira assinada, na função administrativa de uma empresa, ter jogado futebol profissionalmente e trabalhado em uma loja atacadista. No Brasil ter um emprego com carteira assinada significa o trabalhador ter proteção social, pois têm direitos, principalmente o seguro desemprego, as férias remuneradas, as horas extras, o adicional noturno, a licença maternidade ou paternidade, as faltas justificadas, o $13^{\circ}$ salário, o auxílio-doença e aposentadoria.

No que se refere ao emprego que desempenhavam antes de serem catadores. As mulheres todas foram empregadas domésticas, sendo que na avaliação delas a mudança de emprego era positiva, pois não gostavam de receber ordens dos seus patrões, ressaltando que na catação não havia ninguém que dava ordens, bem como existia flexibilidade no trabalho, pois, cada um sabia o que devia ser feito e não havia ninguém para reclamar do serviço. O trabalho dos homens era, predominantemente, de serviços braçais, como ajudantes de pedreiro, trabalho na agricultura ou pecuária e lavagem de carros. As narrativas abaixo corroboram essas percepções:

Ah, melhorou foi muito porque doméstica é outra coisa trabalha mais ainda aqui já é um trabalho assim que não é muito essas coisas mais a gente trabalha para nós mesmos pode se dizer, né. O que eu achei bom foi isso [...] Na casa de família tem muita pessoa que cobra, é isso e aquilo, aquilo e isso, aqui não é tanto igual uma casa de família, né, aí aqui já sabe o nosso dever direitinho, lá a gente sabe na casa de família, mas sempre tem a pessoa pode falar "não é isso, saiu daquele jeito aqui, não é tanto assim também" [...]. Aqui é a gente já sabendo o jeitinho que a gente trabalha como é que é não precisa a pessoa ficar em cima, né, trabalhando direitinho, né, não tem reclamação (CATADORA (1), 30 anos).

Trabalhava em casa de família, houve melhora porque, sei lá, não gosto de ninguém mandando em mim. (CATADORA, 29 anos).

É eu acho melhor trabalhar de catadora [...]. Porque aqui não tem patrão e nós não somos empregados, a gente trabalha pra gente (CATADORA (2), 30 anos).

O único trabalhador que teve emprego com carteira assinada diverge da opinião dos demais, pois ressalta a importância dos direitos trabalhistas. Como relatado abaixo:

Em relação ao salário é melhor, agora em relação a outras condições de ter seguro se acontecer algum acidente, se acontecer alguma coisa contigo é mais complicado porque a gente não tem esse auxilio (CATADOR, 27 anos).

Por fim, quando perguntados sobre a possibilidade ou oportunidade de retornarem as suas cidades natais para viverem, nenhum entrevistado manifestou interesse. Apenas relataram a vontade de visitar os parentes e familiares; encontrar os antigos amigos; e comer comidas típicas da região. Muitos afirmaram que a situação das regiões onde nasceram 
eram precárias e devido a isso preferiam continuar vivendo, morando e trabalhando no DF.

\section{Iniciando o trabalho na catação e a construção do ser catador}

De acordo com os catadores, o início da ocupação requer um período de adaptação devido às condições insalubres que trabalham, principalmente em aspectos relacionados ao ambiente e a exigência do corpo. A presidente da associação relatou que algumas pessoas que ela contratava não conseguiam permanecer uma semana trabalhando. De acordo com os catadores, aqueles que permaneciam deviam passar por um período de adaptação. Como narrado por uma catadora entrevistada:

Foi um pouquinho difícil se acostumar aqui na Usina. Eu fiquei ainda... fiquei uns 2 dias em casa, depois voltei, depois fui, depois acostumei. Achava muito nojento. Quando eu aquele tanto de boró eu começava a vomitar (CATADORA(1), 30 anos).

O trabalho cotidiano faz com que esses trabalhadores encontrem diversos produtos no lixo, tais como brinquedos, celulares, armas de fogo, roupas e dinheiro. Em algumas situações relatadas pelos entrevistados até recém-nascidos mortos já tinham sido encontrados no lixo que era enviado à Usina. Assim como alguns consumiam os remédios encontrados. Diante desse cenário é perceptível que a lida cotidiana com o trabalho envolve situações complexas.

Quando perguntados de como começaram a trabalhar como catadores as respostas foram as mais variadas, desde o pioneirismo e o desemprego até a necessidade de renda para investir no futuro profissional. A maioria deles já possuíam familiares que trabalhavam na catação. Como evidenciado nas seguintes narrativas:

É porque a gente morava lá na invasão, né? A invasão era no carrinho lá no Guará, aí inventaram lá de fazer uma cooperativa, aí perguntou quem queria participar dessa cooperativa e aí eu fui uma delas que queria participar. Aí eles lá deram nome, foram registrar em cartório, foram registrar firma, foram fazer lá, eles lá, e eu participando, sempre participando. Aí quando tirou a gente de lá do Guará, quando botou pra cá, só que não era assim como trabalha aqui, lá cada um trabalhava individual. Aí quando saiu de lá pra cá organizou tudinho, arrumou um canto pra nós tudinho, aí botou nós aqui e estamos trabalhando até hoje (CATADORA, 36 anos).

Não porque, assim, minha sogra é a presidente daqui, aí tipo assim a família toda trabalha aqui, tipo influencia já, entendeu? (CATADORA, 25 anos).

Eu trabalhava em casa de família e fiquei desempregada, aí veio a necessidade, aí eu vim atrás de arrumar um serviço, né e consegui (CATADORA (1), 30 anos).

Através da minha mãe, minha mãe trabalha aqui também, minha mãe e minhas irmãs (CATADORA, 29 anos).

Aqui, na verdade a minha irmã já trabalhava aqui antes porque ela é casada com o rapaz que trabalha aqui, aí eu estava trabalhando antes fichado né, aí sai da empresa e comecei a trabalhar aqui. Aí eu falei com a presidente, aí ela aceitou (CATADOR, 27 anos).

Os catadores se sentem atores importantes para o meio ambiente, mas, ao mesmo tempo, o preconceito vivido e sentido por eles fica marcado nas suas trajetórias de vida. Tal preconceito é reflexo do desconhecimento da sociedade da importância do trabalho desses 
atores para a sustentabilidade. E também pelas relações de poder na sociedade que rodeiam o mundo do trabalho: como as relações de classe; e as desigualdades de raça e gênero.

Em relação ao mercado de trabalho, as questões de raça, gênero e classe não devem ser ignoradas, assim como em outras dimensões da vida social conforme afirmam as intelectuais negras (Hooks, 1995; Davis, 2016; Crenshaw, 2004). "Os homens sofrem grandes males no mundo entre a existência do trabalho e do capital, mas esses males, se comparados com os males das mulheres, diante de quem as portas de mercados e profissões são fechadas com força, não são nem um grão de areia na praia" (Davis, 2016). No âmbito das ocupações, as mulheres negras encontram-se em situações precárias. Isso tem sido explicado pela sua exclusão do mundo do mercado de trabalho por razões de violências culturais que as subordinam ao patriarcado, em que a dicotomia entre o papel feminino assentado na reprodução biológica, com ênfase na maternidade e na realização de afazeres domésticos, e o papel masculino no exercício do poder econômico na esfera pública, foi traçada ao longo de toda a história da humanidade (Melo, Considera, \& Di Sabbato, 2007)

Esse cenário se torna pior ao compreender a realidade das mulheres negras, pois as mulheres racialmente dominantes mesmo em desvantagem ao homem, quando o assunto é o mercado de trabalho, ela consegue emprego mais fácil do que a mulher negra. De acordo com Marcondes, Pinheiro, Queiroz, Querino e Valverde (2013), as mulheres negras configuram o segmento que mais sofre com o racismo e machismo, pois são as últimas a se inserirem no mercado de trabalho. Para Crenshaw (2004) as mulheres negras não têm condições de concorrer adequadamente no mercado em decorrência dos poucos empregos disponíveis, assim tendem a ser mulheres socialmente marginalizadas.

Apesar dessas desigualdades de saúde marcarem o contexto dos catadores, principalmente da mulher catadora. Existem particularidades do ser catador que os diferencia de outros grupos sociais, fazendo com que produzam seus próprios conhecimentos e práticas para driblar as marcas sociais arreigadas pelas suas condições de trabalho e a estrutura desigual da sociedade. Na lida cotidiana eles citaram a questão social do preconceito, especialmente quando iam até as lojas para comprarem produtos. Para driblarem as situações desconfortáveis eles utilizavam estratégias para minimizar o desconforto, causado ao falarem que trabalhavam com o lixo, assim se definiam como autônomos e não como catadores de materiais recicláveis.

O preconceito perpassava pelos relatos dos entrevistados e deixava marcante que a sociedade os configurava como indivíduos que trabalhavam no lixo, assim a atividade é marcada pelo preconceito vivido e sentido por eles (Santos \& Silva, 2009), deixando marcas nas suas vidas. Embora alguns relataram não terem vergonha, gostando de afirmar a posição da ocupação. As narrativas seguintes corroboram isso:

Eu acho né que a gente ajuda o meio ambiente, mas eu acho que ainda é muito descriminado, sei lá, quando a gente fala assim que trabalha no lixo, aí eles ficam meio assim, tipo, sei lá, tipo com nojo, sei lá. [...] Assim se a gente vai em uma loja, "trabalha de que?", “de reciclagem”, aí eles ficam meio assim (CATADORA, 25 anos).

Vixe, sei lá, tem hora que fico até com medo de falar porque com medo deles criticar, né, nossa a gente trabalha no lixo, catadora né, isso. Eu fico até com medo 
de falar, né, “qual é a sua profissão?” Eu fico caçando jeito pra falar pra eles não criticar, mas eu falo. Tem preconceito, eu acho, principalmente, quando fala que é catadora de lixo, pronto né (CATADORA, 36 anos).

É um pouco diferente né quando a gente vai falar a questão do emprego aí, assim, a pessoa tipo trata diferente a gente, mas assim eu me sinto bem [...]. Eu acho, assim, acho o emprego diferente da gente, a gente trabalha assim porque não é um emprego que todo mundo que trabalha, entendeu? Não é comum né, aí é um pouco diferente (CATADOR, 18 anos).

Na maioria das vezes eu falo que eu sou autônoma, né, não falo que trabalho aqui, sou autônoma, trabalho pra mim mesmo [...]. Fica mais fácil, né, quando responde isso eles não perguntam mais nada (CATADORA (1), 30 anos).

O significado do lixo na percepção dos catadores era o produto que gerava renda para o seu sustento, aquele material que separado da sujeira tinha valor agregado. A sujeira estava misturada no lixo, porém, após o trabalho de triagem do material e separação, a sujeira era descartada e o lixo reaproveitado, tornando-se um produto para a venda. Embora alguns ainda não conseguiam fazer essa distinção, outros manifestaram conhecimento do trabalho desenvolvido e sua função social para o meio ambiente.

Sujeira é aquela coisa que não tem mais o que aproveitar, né. E o lixo não, você tem ainda o que reciclar daquele lixo ali, tem alguma coisa pra você reciclar do lixo, né (CATADORA, 36 anos).

Ah, o lixo, tipo assim [...] tipo, igual ao lixo, nós vivemos na sujeira porque aqui tem muita bactéria, acho que aqui é sujeira. Mas lixo é o que as pessoas [...] igual lá em casa, não separa o material reciclável do que não é reciclável pra mim é lixo, o que não serve mais [...]. Nós separamos do lixo, separa o material reciclável do lixo (CATADORA, 25 anos).

Porque na verdade tá tudo englobado na mesma coisa, né, porque o lixo e a sujeira já estão tudo junto, aí o que a gente faz é separar esse material. [...]. A gente separa o lixo né e a sujeira ela é descartada, o que não presta (CATADOR, 27 anos).

Os catadores estavam inseridos em um ambiente dinâmico, do ponto de vista das relações interpessoais no trabalho, haja vista a boa relação entre os colegas, fato esse que talvez se justifica por muitos serem parentes e residirem no mesmo bairro. A maioria significativa desejava continuar sendo catador. O desemprego e o desafio de se obter um emprego com carteira assinada nos dias atuais eram barreiras explícitas para que almejassem um novo emprego com condições melhores de trabalho. Como presente nas narrativas:

Por enquanto aqui pra mim tá bom, tá ótimo aqui, mas não sei daqui pra frente né, se arrumar um emprego melhor. Mas, por agora, tá bom (CATADOR, 18 anos).

Mais pra frente se eu ver que as coisas, pode ser que as coisas melhora mais de emprego, aí eu posso, não sei né, não posso sair porque a coisa está feia né. $\mathrm{O}$ desemprego tá grande né, você arrumar um emprego fichado hoje em dia pra ganhar bem é difícil, é meio difícil, é complicado (CATADOR, 25 anos).

O grupo social de catadores sabem de importância social e ambiental de trabalho, mas enfrentam o preconceito daqueles que percebem a catação como mexer com lixo. A presença da associação e encontros de catadores fomentam a resistência e sua importância social (Vasconcelos et al., 2018). 


\section{As condições de trabalho dos catadores e os problemas sanitários da ocupação}

Os horários de trabalho na Associação correspondiam aos turnos diurno e noturno, durante o período diurno as atividades eram realizadas no galpão de triagem de materiais reciclados, com quinze catadores, onde era feita a separação do material e a limpeza, tudo de forma manual, com exceção do uso da prensa. O horário de entrada do turno diurno correspondia às $7 \mathrm{~h}$, possuíam pausa para almoço das $11 \mathrm{~h} 40$ até $12 \mathrm{~h} 40$ e a saída ocorria às $15 \mathrm{~h}$. No período noturno na Usina trabalhavam 45 catadores, sendo a maioria mulheres, devido à concentração do trabalho ser na separação dos materiais nas esteiras. Dois dos catadores trabalhavam somente na parte administrativa, a presidente e o secretário. No turno noturno, a Usina funcionava das $22 \mathrm{~h}$ às $6 \mathrm{~h}$.

No ambiente de trabalho, às vezes, as decisões governamentais sobre as normas de funcionamento do local eram verticalizadas, como relataram alguns catadores, não ocorria diálogo com eles sobre as mudanças estruturais que acabavam modificando o cotidiano do espaço. Durante o campo destacaram o aumento da segurança onde trabalhavam, embora segundo os entrevistados, não melhorou nada a segurança dos trabalhadores, pois o espaço ainda era aberto nas laterais da Usina, existia casos de roubos de materiais no local.

Os carros não podiam mais rodar sem autorização até o galpão de triagem de materiais, nem mesmo a van que transportava os próprios trabalhadores, com essa medida os mesmos tinham que caminhar uma distância considerável no sol ou chuva, além disso caminhar entre as áreas de compostagem, que possuía a presença intensa de mosquitos e moscas. Segundo os catadores, a mudança foi para evitar atropelamentos e acidentes entre carros, haja vista que havia uma grande movimentação por conta da pesagem dos caminhões de lixo.

Porém, apesar da busca dos integrantes do governo por mais segurança, na avaliação dos catadores, as alterações os prejudicaram, principalmente as mulheres. Além dos problemas climáticos, as mulheres catadoras após essa intervenção governamental relataram um outro problema, as mesmas se sentiam assediadas, a partir do momento em que começaram a fazer esse trajeto a pé, pois no espaço trabalhavam muitos homens de outras instituições, onde nas idas e vindas do percurso do estacionamento ao galpão, que as assediavam com piadas e cantadas grotescas.

Os catadores utilizavam uniformes para trabalhar, sendo considerado um Equipamento de Proteção Individual (EPI) e durante todo o campo foi observado que na rotina de trabalho somente eram utilizados como EPI: o uniforme, as botas e as luvas. As máscaras para proteção da respiração e os óculos para proteção dos olhos não eram utilizados. Ressalta-se a importância do uso de todos os equipamentos, pois o cheiro forte do lixo é uma realidade cotidiana que pode estar relacionado aos elevados casos de doenças respiratórias, muito presente na realidade desses trabalhadores. Do mesmo modo, alguns catadores durante a separação dos materiais recicláveis no galpão constantemente fumavam cigarros.

Em relação à divisão das atividades, os homens realizavam os trabalhos mais pesados, como a prensagem do material, embora as manipulações dos fardos eram feitas por homens e mulheres que também exigiam grande esforço físico. Essencialmente, a divisão do trabalho é feita por gênero, as mulheres ficam com a função de separar e triar as sedas 
e os homens nas latinhas de desodorante com martelos, tirando as partes plásticas que são descartadas, e na prensa do material.

Especificamente, a realidade do contexto aponta para o que Hirata (2009) chama de divisão sexual do trabalho, corrobora o pensamento da existência de trabalhos de homens e trabalhos de mulheres. Ao contrário do encontrado no estudo de Ribeiro, Nardi e Machado (2012), onde as mulheres executavam o trabalho "pesado" e tinham o status de quem "aguentava o tranco", na realidade do contexto estudado as catadoras não executavam o trabalho mais "pesado". Embora, destaca-se que a visão delas era que os homens da associação não aguentavam o trabalho pesado do dia a dia. Em contrapartida, o trabalho na prensa do material, que exigia maior esforço físico eram delegados aos homens pela razão de terem mais força. Como afirmam Ribeiro et al. (2012), quando as mulheres se percebiam como mais fortes que os homens, elas estavam se referindo não apenas à questão de força física, mas também à ideia de perseverança e responsabilidade, expressa no cuidado com os filhos, com a casa e consigo mesmas.

A rotina dos catadores após um dia de trabalho era diversificada, entretanto havia diferenças marcantes entre as mulheres e os homens. As mulheres possuíam uma rotina densa, principalmente, por causa do cuidado com os filhos e pela responsabilidade instituída por serem donas de casa, logo todas elas se intitulavam pai e mãe ao mesmo tempo. O fato de serem "pamãe", que segundo as catadoras era a junção de pai com mãe, devido à intensa rotina de trabalho que viviam e ainda serem cuidadoras do lar, sendo responsáveis por responderem pela maioria do problemas famíliares. Essa condição contribuiu para uma situação de maior comprometimento da saúde feminina quando comparada com a masculina. Como presente nas narrativas abaixo:

Então estressa, você chega, ainda mais no caso da mulher... a mulher ainda chega em casa e tem que cuidar da casa, o homem não, o homem chega em casa, sentou e pronto. Tomou banho, sentou e pronto. Mulher não. A mulher ainda vai cuidar da casa, sabe que quando chegar tem que... é obrigada a fazer comida, cuidar de criança, essas coisas, é cansativo. Então já sei o que vai acontecer amanhã: vou trabalhar, vou chegar e vou ter que arrumar a casa. A gente já fala aqui "nossa, hoje é dia de lavar roupa" "eu também"... aí a gente já sabe a nossa rotina (CATADORA, 23 anos).

É a rotina do dia a dia né, a gente cansa... serviço, casa, menino. A gente se sente cansada. Tem uma hora que o corpo da gente cansa né? (CATADORA, 29 anos).

$\mathrm{Na}$ lida cotidiana, as mulheres reclamavam de excessivas dores nas juntas, joelhos e câimbras nas costas, devido à posição de agachamento constante na triagem e na separação dos pets, plásticos e papéis. Os homens não reclamam de dores, mesmo desenvolvendo o trabalho na prensa, o que fisicamente exige maior uso da força. Percebese que essa questão do desgaste não está relacionada somente com o trabalho em si, pois concorda-se com Ribeiro et al. (2012) quando dizem que que um dos fatores que tornam precário o cotidiano da mulher catadora é a série de atribuições e responsabilizações que lhe são colocadas tanto no espaço público quanto na esfera doméstica. Essa situação que afeta o bem-estar dos trabalhadores é típica do trabalho com a catação como encontrado em outros estudos (Alencar, Cardoso, \& Antunes, 2009; Alexandrino, Ferreira, Lima, \& Makkai, 2009). Assim acrescentadas a essa situação encontram-se as vidas precarizadas e vulnerabilizadas das catadoras. 
Além disso, percebeu-se que as catadoras se situavam em um contexto desconfortável para a sua saúde, tanto física quanto psicológica, para questões além do trabalho, principalmente, no que se referia aos relacionamentos conjugais, fato esse encontrado também no contexto estudado por Ribeiro et al. (2012). A violência doméstica deixa marca na vida das catadoras, das seis mulheres entrevistadas cinco delas relataram terem sido agredidas, sendo que duas ainda conviviam com os agressores. Tal problemática apresentada nas narrativas abaixo:

Eu e meu marido, a gente já se pegou no boxe [...] uai, o policial foi bater lá, aí eu falei que era mentira. Porque se eu falasse que era verdade, Deus me livre, ia prender ele. (..) ai ele falou "não, isso é mentira, não é verdade não" (CATADORA (1), 30 anos).

Ele me agrediu depois de nós separados [...] eu fiz uma ocorrência, deu 3 ocorrências seguidas em menos de 15 dias... ele me agrediu né, 3x, menos de 15 dias ele me agrediu (CATADORA, 29 anos).

No que se refere ao ambiente, existia o convívio com muitos insetos e animais peçonhentos, potenciais geradores de doenças, como mosquitos, moscas, pombos e baratas, destacando-se a quantidade excessiva de pombos no local. Inicialmente, este impacto visual, táctil, sensorial do trabalho é central na adaptação, de transformação dos sentidos para estar no trabalho. Os catadores ressaltaram que o piolho do pombo é uma praga, por isso tentam constantemente combater a proliferação desses animais no seu ambiente de trabalho, jogando pedras ou cobrando a dedetização por parte das organizações governamentais, mas que não surgiam efeitos pois no local tinha a presença constante desses animais, mostrando o desamparo pela ação do Estado.

A respeito da alimentação durante o horário de trabalho, era rica em carboidratos, principalmente, na quantidade de arroz ingerida, só se alimentavam no período do almoço, apenas tomavam água ou café no período que estavam trabalhando. $\mathrm{O}$ espaço para a alimentação era no próprio galpão, o que não configurava como o local ideal para realização das refeições, uma vez que na sala havia muitos entulhos e a presença de pombos, moscas e mosquitos.

Geralmente, as mulheres comiam sentadas na mesa de uma sala e interagiam entre si e, por sua vez, os homens comiam e interagiam entre si nos sofás velhos do lado de fora da sala do galpão de triagem de materiais. Em alguns momentos as catadoras que não levasse comida, o grupo a dividia com quem estava sem refeição. As marmitas não eram acondicionadas adequadamente, ficando expostas em uma mesa de alumínio localizada dentro da sala do galpão de triagem de materiais até a chegada do horário de almoço. 


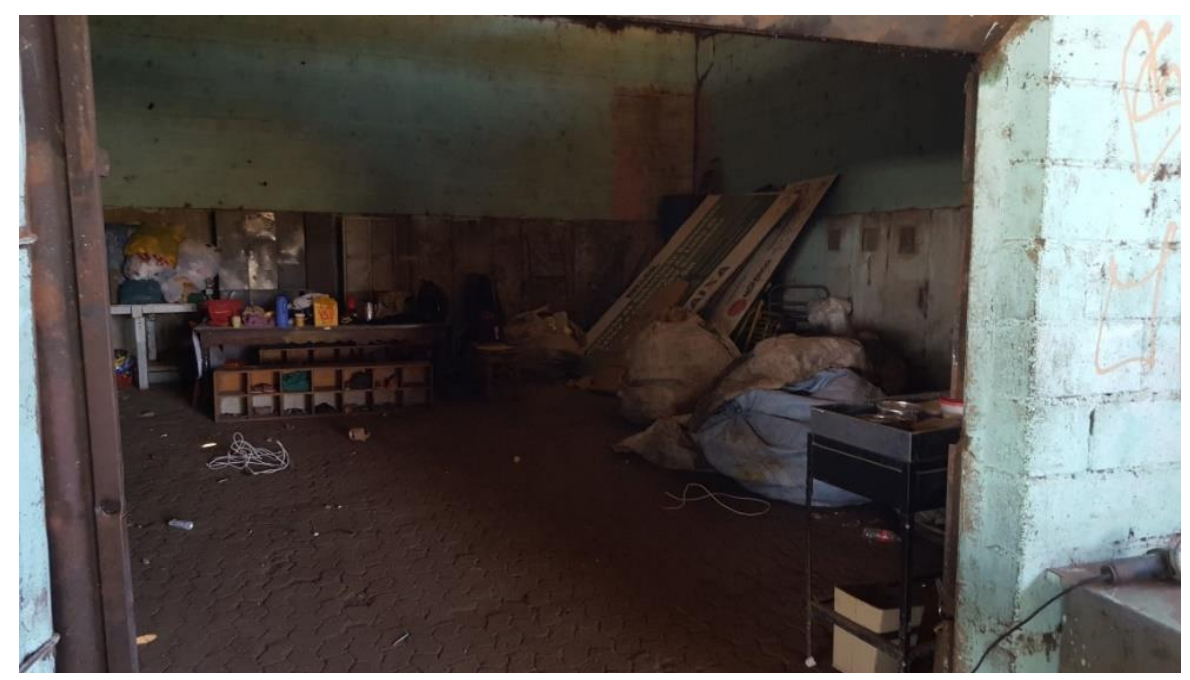

Figura 3. Sala do galpão de triagem de materiais da Usina.

Em relação à qualidade do ambiente de trabalho, uma das reclamações dos catadores era referente à qualidade da água, alguns relataram que já tinham passado mal devido ao consumo da água disponível para consumo na Associação. E com isso, alguns passaram a trazer de casa, mas ainda era expressivo o número deles que tomavam água na torneira ou retiravam a água da torneira e colocavam na geladeira, afirmavam que quando a água estava gelada dava para beber, quente não. Como evidenciado nas narrativas abaixo:

Já é também por causa do problema de urina também, porque eu fiz os exames de sangue e de urina e constou bactéria na urina e no sangue, aí ele falou que pode ser alguma coisa que eu estou ingerindo e é a água daqui, por isso, que agora a gente está trazendo a água de casa, porque a água daqui é poço artesiano, aí a água sobe do poço e eles jogam pra caixa d'água. Mas a caixa tem hora que a água sai podre, fedendo, sai com sujeira dentro né, porque fica acumulando e aí a gente bebe e nessa quentura a água sai quente, quente. A gente bebe, dá dor de barriga, todo mundo aqui fica com dor de barriga e agora pra evitar estamos trazendo de casa a água (CATADORA, 23 anos).

Ixe, a água daqui, Deus me livre, tá horrível a água aqui, quente que só meu Deus do céu. A gente bebe ali, dá dor de barriga. A gente tá pegando ali de cima, tem vez que traz de casa (CATADORA (1), 30 anos).

Dessa maneira, o contexto do trabalho além de ter elementos prejudiciais à saúde por sua natureza, como o uso excessivo da força, a posição constante de agachamento, a sujeira do local, o cheiro forte do lixo, o contato com animais peçonhentos, o risco de acidentes com materiais perfurocortantes, particularidades específicas inerentes ao cotidiano do ser catador, essas condições refletem nas doenças e nos agravos à saúde produzidos naturalmente pelo cotidiano da ocupação. Todavia somadas a isso o que foi encontrado na realidade reflete também total desamparo desses trabalhadores por parte das instâncias governamentais, mesmo o espaço sendo de responsabilidade do poder público, não existia se quer um banheiro adequado para os trabalhadores fazerem suas necessidades básicas ou água tratada para consumo humano, revelando-se como um espaço insalubre que poderia ter condições de trabalho menos prejudiciais à saúde caso tivesse uma atenção por parte do Estado. Como narrado por elas: 
Deixa eu ver, tipo assim, igual aqui óh, tipo assim, antigamente a gente comia comida fria, aí deu azia, já deu gastrite, aí, tipo assim, aqui não tem banheiro, o banheiro ali está um caos, a gente vai fazer xixi lá, rum, aí vai ter que ir no hospital porque começa a dar coceira na vagina. A dificuldade agora é esse banheiro. Porque, tipo assim, lá o vaso está uma nojeira, a gente tá fazendo xixi no chão, aí as bactérias entram né, porque o médico falou já que a gente faz xixi e o vapor entra na vagina aí dá infecção (CATADORA, 25 anos).

Já é também por causa do problema de urina também, porque eu fiz os exames de sangue e de urina e constou bactéria na urina e no sangue, aí ele falou que pode ser alguma coisa que eu estou ingerindo e é a água daqui (CATADORA, 23 anos).

Existem os riscos cotidianos inerentes a atividade de catação como o contato com animais peçonhentos e a contaminação por materiais perfurocortantes presente nas narrativas:

A gente trabalha aqui, tem muitos pombos e esses pombos já transmitem doenças. O pelo deles, o piolho do pombo que tem também, já transmite doença né. Se a gente respirar o pelo dele é pior até pode parar no hospital, quem tem asma também, a poeira que é muita aqui, de vez em quando eles passam com o caminhão e despeja água, mas não adianta e acontece contaminação porque a gente mexe com lixo, tem hora que a gente pega agulha que é de gente diabética e a luva não protege, né, só protege da sujeira, mas não protege da picada. Graças a Deus até hoje a gente nunca sofreu não, mas caco de vidro e se cortar, essas coisas assim, então tem sim bactéria em banheiro, porque o banheiro aqui é muito sujo então as mulheres todas aqui tem bactérias, pega bactérias no banheiro porque a gente não utiliza o vaso utiliza o chão, né, porque a gente não é homem, homem faz em qualquer lugar né, mas a mulher tem que ser no banheiro, então a gente lava, mas não adianta porque os homens usam também e faz aquela nojeira só (CATADORA, 23 anos).

Eu já sim quando eu trabalhava rasgando o lixo, a gente rasgava o lixo mesmo, a gente trabalhava lá embaixo no sol quente, só que graças a Deus agora já organizou tudo sabe, só que mesmo assim ainda é perigoso ainda essa seda mesmo a gente fura o dedo, porque vem agulha essas coisas (CATADORA (2), 30 anos).

As questões referentes à falta de infraestrutura digna de trabalho perpassam pela realidade cotidiana de trabalho de catação dessa Associação, desde a falta de qualidade da água para consumo até a indisponibilidade de um banheiro adequado para uso. Houveram relatos de que a maioria das mulheres já tinham adquirido infecção urinária e outros tipos de infecções, sendo que elas acreditavam que era devido às condições do banheiro. Uma das catadoras relatou que as trabalhadoras já tinham procurado providências às instâncias competentes, como a CAESB (Companhia de Saneamento Ambiental do Distrito Federal) responsável pelos abastecimentos de água e serviços de esgotamento sanitário em todas as cidades do DF. A busca era para a solução dos problemas locais, mas nada ainda tinha sido feito até o momento da pesquisa. Como narrado abaixo:

[...] estamos cobrando, porque para as mulheres é difícil infecção urinária e outras infecções até piores a gente pega também. A gente já pediu solicitação para Valor Ambiental para arrumar, eles só vêm, tiram foto e nada, até hoje o banheiro está lá do mesmo jeito. Aí pedimos pra fazer um aqui dentro do galpão, disse que não pode, aí esse dia trouxe a CAESB pra ver se dar pra puxar um cano de esgoto aqui pra gente, porque desse jeito não dar, porque tá tendo muita doença mais de acordo com o banheiro (CATADORA, 23 anos). 
Para os entrevistados, a questão do cuidado à saúde era colocada em segundo plano devido à necessidade financeira do trabalho. Na percepção da maioria, a sua condição de trabalho influenciava negativamente na sua condição de saúde, tendo a noção de que o exercício da atividade desencadeava doenças. O estudo de Vasconcelos et al. (2018) também revela essa situação constante na vida dos catadores. Para alguns, tais doenças oriundas do trabalho de catação já são naturalizadas, o que não provoca mais angústia, pois não deixam de trabalhar quando adoecem, mas não tem como naturalizar a situação das mulheres. Na verdade, percebe-se que, como classe social que depende do trabalho, há um processo de naturalização das condições precárias do trabalho e dos danos à saúde, imposto pela situação mais ampla de violência de suas vidas, das poucas chances de terem outra ocupação e da necessidade latente de sustento.

Os catadores destacaram que as doenças predominantes eram as respiratórias, como gripes e resfriados, febres e dores de cabeça. Durante a pesquisa de campo todos participantes adquiriram problemas respiratórios ao longo dos meses. Em outro estudo realizado por Porto, Juncá, Gonçalves e Filhote (2004) existe semelhanças nas doenças mais predominantes com a realidade empírica desta pesquisa.

As dores corporais, gripes e as dores de cabeça constantes não são consideradas como problemas de saúde que as impedem de comparecer ao trabalho. Os catadores costumavam trabalhar mesmo adoecidos, pois a necessidade de sobrevivência era maior do que a sua saúde, caso não comparecesse ao trabalho por motivo de doença, ele não recebia pelo dia que tinha que se ausentar, por isso, a maioria preferia ir trabalhar mesmo doentes. $\mathrm{O}$ fato de estarem enfermos constantemente por esses sintomas também ajudava para manutenção desse cenário. Alguns destacaram que quando estavam doentes e trabalhavam a situação piorava, porém, mesmo assim não deixavam de trabalhar, como é possível ser observado nas narrativas abaixo:

Sim, mas doença assim normal, gripe, dor de cabeça né, dor nas pernas [...]. A gripe e a sinusite que demora mais pra ir embora, mas a não ser as dores nas pernas é normal mesmo, os exercícios aqui, a posição só né, ai doi fica mais agachada, aí doi as pernas (CATADORA, 36 anos).

Não, ás vezes a gente pega uma gripe, aí a gente vem trabalhar e aí fica mais forte, dá dor de cabeça, febre (CATADORA, 25 anos).

Dores nos braços, nas pernas, nas costas, devido ao movimento, né, da gente abaixar, levantar, pegar e puxar, é tanta coisa (CATADORA (1), 30 anos).

Traz em relação ao respiratório, porque a gente trabalha em um ambiente contaminado, em relação ao contato com material que pode pegar alguma bactéria, alguma doença relacionada à seda que a gente trabalha mesmo aqui, em relação a isso traz (CATADOR, 27 anos).

Esse cenário revela a violência onde estão inseridos e impostos a uma margem social. De acordo com Kleinman, Veena e Lock (1996), forças sociais causam prejuízos à experiência humana e a vida de catadores revelam essa forças. Há um sofrimento social, de acordo com esses autores, que resulta do que o poder político, econômico e institucional fazem com as pessoas e do que essas formas de poder elas mesmas influenciam respostas a problemas sociais. No caso dos catadores, as repostas são exclusão e vulnerabilização de suas vidas. A situação precária dos catadores revela uma situação de pobreza que é um fator de risco para o adoecimento. 
Os marcadores de intersecção das relações sociais de gênero, raça e classe marcam a vida das mulheres negras catadoras, essas são mais vulneráveis, pois estão inseridas em um contexto do trabalho produtivo precário, uma vez que cuidam das suas casas/lares e filhos, e ainda sofrem violências. Embora o contexto mostre que mesmo as mulheres estando desamparadas por parte das ações e intervenções do Estado, elas acionavam sua rede de apoio social, que passou a ser uma estratégia de cuidado e manejo de vida para enfrentamento dos problemas sentidos no cotidiano, pois os vizinhos, as amigas catadoras e a religião cumpriam o papel do suporte assistencial nessa problemática, sendo uma maneira de agenciar o cuidado à saúde. Os vizinhos denunciavam quando ocorrido perto das residências, as amigas catadoras compartilhavam experiências e sentimentos, além de trocarem afetos, compartilhamentos de angústias e desejos entre elas, e a religião significava a transformação social e a salvação.

No trabalho dos catadores de materiais recicláveis estão imblicados subjetividades e práticas de resistências, como a organização coletiva no sindicato, a rede de apoio entre catadores, o uso de terapias populares para o cuidado à saúde e a rede de apoio feminina. Apesar das desigualdades impostas pela sociabilidade capitalista, pois nesse contexto estão pessoas historicamente reprimidas pelo modelo socioeconômico, a população feminina e a negra. As características da realidade desse tipo de trabalho estão marcadas pela classe social que pertencem, são pessoas subjulgadas desde o início das suas trajetórias de vida evidentes pelo contexto do trabalho infantil e baixa escolaridade. Diante disso, a saúde se torna abalada pelos marcadores sociais de gênero e cor da pele; estando agravada ainda pela total ausência de bem-estar no trabalho. Ainda assim carregam em suas vidas os estereótipos negativos, que colocam a população negra e, sobretudo as mulheres negras, em situação de desvantagem e vulnerabilidade no acesso aos serviços de saúde, assim como de violência, violação e negação a vida" (Goes \& Santos, 2014).

Com isso no contexto desse grupo social os procedimentos terapêuticos alternativos para melhoria das suas condições de trabalho e vida partem da organização deles mesmo, para o cuidado com à saúde envolvem a utilização de práticas medicamentosas e saberes populares de cura; para os problemas mais complexos como a violência as redes de cuidado feminina são acionadas; a vizinhança e os colegas de trabalho tem a função de ajudar quando necessitam em todas as dimensões; e a religião exerce para eles a percepção da melhoria de vida. Na luta diária por condições de infraestrutura mais adequadas no trabalho eles se articulam coletivamente em reuniões com o poder público. São trabalhadores em estreito diálogo com o poder público no cumprimento da organização de alternativas de gerenciamento dos resíduos sólidos urbanos e ao mesmo tempo vivem, se submetem e resistem a condições desumanas. Eles abastecem a indústria da reciclagem, ou seja, esses trabalhadores são elos indispensáveis para a consolidação da sustentabilidade por meio da gestão dos resíduos sólidos nos centros urbanos, ao mesmo tempo fazem parte da cadeia produtiva da reciclagem gerando matéria-prima reciclada de alto valor econômico para o mercado. $\mathrm{Na}$ ausência dos catadores o processo de produção não se tornaria viável, haja vista que as máquinas sozinhas ainda não conseguem realizar todo o trabalho de transformação do lixo em mercadoria. Os catadores, embora desempenhem um papel fundamental na cadeia produtiva, representam o elo mais frágil de todo o sistema (Zaneti, Sá, \& Almeida, 2009).

Em contrapartida, a base da reciclagem se configura também, de maneira marcante e contraditória, pela exploração dos corpos de homens negros e principalmente mulheres 
negras, que desenvolvem suas atividades laborais em situações precárias, sem nenhum direito trabalhista garantido pela lei e políticas sociais ineficientes que não atendem suas necessidades. A expropriação da classe trabalhadora marca a disponibilidade da atividade humana em prol do capital onde essa passa a ser convertida em mera força de trabalho (Fontes, 2010).

O estreito contato com o poder público, ainda os submetem a condições precárias e insalubres, ao mesmo tempo que eles contribuem na obtenção de lucro por parte dos atravessadores e das indústrias de reciclagem, historicamente o contexto dos catadores de materiais reciclados mostra a desvalorização da dimensão da vida humana. Paralelamente a maioria das associações/cooperativas funcionam em espaços cedidos pelo poder público. Nessa perspectiva tem-se o entendimento de Mandel (1982), o Estado serve para manter a classe operária inerte contra o sistema capitalista, assim permanece a alienação do trabalhador que identifica as causas da sua ocupação como naturais e flexíveis.

Por isso, na discussão apresentada existe a ausência da ação do Estado para efetiva proteção social desses trabalhadores. O entendimento do papel do Estado, não como meramente um mecanismo de proteção para os que necessitam de sua assistência, mas também como espaço de arena que envolve complexas relações de disputas sociais e econômicas, sendo um espaço político que atua garantindo o equilíbrio do sistema capitalista, através da defesa do interesse do capital e mediação dos conflitos. Assim confirmando a premissa do pensamento marxista referente ao Estado moderno, quando o categoriza como um comitê para gerir os negócios da burguesia (Marx \& Engels, 1968). Contraditoriamente, o poder público aposta incondicionalmente no discurso da inclusão social dos catadores de materiais recicláveis, gerando emprego e renda, por meio do apoio de cooperativas e associações (Freitas \& Fonseca, 2012). A reciclagem é uma alternativa importante para o gerenciamento dos resíduos sólidos urbanos, pelo processo elevado de consumo e produção de produtos cada vez mais descartáveis.

Segundo Alves e Oliveira (2013) a catação de lixo está inserida nas dimensões da precarização do trabalho disfarçada de estratégia de sobrevivência, já que a lógica de produção capitalista gera a massa de trabalhadores que são obrigados a se sujeitarem a condições cada vez mais precárias e péssimas condições de trabalho. Embora o lixo não representa apenas um problema ambiental, mas também evidencia um problema de dimensão social, pois dentro de uma sociedade capitalista excludente, ele se transforma em uma oportunidade e muitos daqueles que não tem emprego e nem condições de prover sua família (Alves \& Oliveira, 2013).

Esse quadro localizado historicamente e socialmente, acompanhado do aumento do desemprego e a situações de pobreza, ocasionados pelo sistema capitalista, favoreceram para o aumento da quantidade de pessoas que vivem da atividade de catação do recicláveis como forma de sobrevivência e resistência. Para os autores Carneiro, Araújo e Silva (2015) o número de associações/cooperativas voltadas à catação dos resíduos sólidos tende a ser uma ocupação em crescimento devido à precarização, ao desemprego e às informalidades trazidas com as mudanças no mundo do trabalho, a partir da reestruturação produtiva.

A promoção de ambientes de trabalho mais saudáveis, a recuperação da saúde e a prevenção de doenças, mesmo que atendam esses trabalhadores exclusivamente nas suas singularidades, não conseguirão mudar a lógica de exploração e desigualdades que são 
marcas estruturais da sociedade capitalista, ou seja, o grupo social de catadores estarão constantemente inseridos em condições de vida e trabalho precárias, em situações que comprometam a qualidade de vida, sendo que em algumas realidades cotidianas as situações chegam a comprometer a dignidade da pessoa humana, caso a ordem da sociedade não se transforme ou as políticas públicas sejam colocadas em prol da sociedade para o estabelecimento de um verdadeiro bem-estar dos trabalhadores.

Esse cenário aponta as limitações deste estudo que focou compreender as condições de trabalho e saúde, mas que na prática os fenômenos sociais mais complexos apareceram com significados marcantes em suas vidas, como a relação gênero, raça e trabalho. Assim aponta-se a necessidade de estudos mais densos para compreensão dessas macroestruturas de desigualdades presentes na vida cotidiana do ser catador e de muitos outros trabalhadores assalariados. Apesar de com todo esse cenário prejudicial para à saúde, eles manifestam subjetividades positivas sobre o exercício do seu trabalho e o ser social que amenizam suas situações precárias de trabalho e saúde.

\section{Considerações finais}

O trabalho é um fator gerador e modificador das condições de viver, adoecer e morrer dos homens, sendo o tipo de trabalho e sua posição social, fatores determinantes na produção das doenças. Com esse contexto o cenário de trabalho da catação mudou, mas ainda permanecem problemas oriundos do trabalho e da posição social ocupada pelos catadores na sociedade. Não há reconhecimento por parte do poder público desse grupo social, que fomente ações em saúde direcionadas aos mesmos e atendam suas demandas, proporcionando melhores condições de vida e trabalho.

A realidade social de vida, trabalho e saúde dos catadores de materiais recicláveis apresenta dificuldades complexas na resolução dos problemas de saúde relacionados as condições de trabalho, pois estão em situações precárias de subsistência e se encontra marginalizados na sociedade. Eles estão inseridos no contexto de exploração e expropriação características da sociedade capitalista. Contraditoriamente, mesmo sendo uma ocupação de grande importância para a agenda ambiental do Estado esses são totalmente desamparados pelas políticas públicas ambientais e de saúde.

A saúde ocupacional é uma importante estratégia para garantir o bem-estar dos trabalhadores e contribuir efetivamente para a produtividade, motivação e satisfação no trabalho. Porém, estratégias para melhorar somente a situação de saúde não são suficientes para minimizar o contexto de vulnerabilidade social dos catadores de materiais recicláveis que se sentem desamparados pelo Estado, tanto no seu ambiente de trabalho quanto na sua vida cotidiana. Assim necessitando de políticas sociais efetivas de inclusão e uma sociedade mais justa.

De fato, o contexto da sociedade capitalista, produtora de desigualdades, afeta diretamente a vida dos catadores de materiais recicláveis, por sua vez evidenciam o cenário de exploração que estão submetidos, pois dentro do sistema capitalista esses trabalhadores são obrigados a submeter-se as condições precárias de trabalho para o seu próprio sustento ou de suas famílias. As narrativas dos catadores revelam como estão expostos a situações que prejudicam à saúde, seja no próprio ambiente de trabalho, diante de elementos que os expõe naturalmente a doenças ou na própria sociedade desigual que vivem e resistem, estando várias dessas situações relacionadas à posição socioeconômica, 
de classe social, raça e gênero, que ocupam na sociedade, principalmente destaca-se as opressões cotidianas na vida das mulheres catadoras.

\section{Referências}

Alencar, M. C. B., Cardoso, C. C. O., \& Antunes, M. C. (2009) Condições de trabalho e sintomas relacionados à saúde de catadores de materiais recicláveis em Curitiba. Rev. Ter. Ocup. Univ. São Paulo, 20 (1), 36-42.

Alexandrino, D. F. L., Ferreira, M. E. C., Lima, C. L., \& Makkai, L. F. C. (2009) Proposal of social inclusion and improvement of the quality of life and health of collectors of recyclable materials of Viçosa - MG Through the physical activity. Fit Perf J, 8 (2), 115-22.

Almeida, J. R., Elias, E. T., Magalhães, M. A., \& Vieira, A. J. D. (2009) Efeito da idade sobre a qualidade de vida e saúde dos catadores de materiais recicláveis de uma associação em Governador Valadares, Minas Gerais, Brasil. Ciência \& Saúde Coletiva, 14 (6), 2169-80.

Alves, A. K. S., Oliveira, A. M. (2013) Estado, capitalismo e questão ambiental: interfaces no trabalho dos catadores de materiais recicláveis. Recuperado em 04 novembro, 2019, de https://semanaecopol.files.wordpress.com/2013/10/gt-6-anakarina-da-silva-alves-estado-capitalismo-e-questc3a3o-ambiental.pdf

Carneiro, E. M., Araújo, L. B. C., Silva, P. R. C. (2015) Capitalismo, trabalho e Estado: a condição dos trabalhadores catadores de materiais recicláveis no contexto de estado neoliberal. Recuperado em 04 novembro, 2019, de http://www.joinpp.ufma.br/jornadas/joinpp2015/pdfs/eixo2/capitalismotrabalho-e-estado-a-condicao-dos-trabalhadores-catadores-de-materiaisreciclaveis-no-contexto-de-estado-neoliberal.pdf

Companhia de Planejamento do Distrito Federal (2015) Pesquisa Distrital Por Amostra de Domicílios - Ceilândia - PDAD. Recuperado em 01 novembro, 2019, de http://www.codeplan.df.gov.br/images/CODEPLAN/ PDF/Pesquisas\% 20Socio econ\%C3\%B4micas/PDAD/2011/PDAD\%20Ceil\%C3\%A2ndia-2010-2011.pdf

Crenshaw, K. (2004) A Intersecionalidade na discriminação de raça e gênero. In: V. A. Cruzamento: raça e gênero. Brasília: Unifem. Recuperado em 05 novembro, 2019, de http://www.acaoeducativa.org.br/fdh/wp-content/uploads/2012/09/KimberleCrenshaw.pdf.

Creswell, J. W. (2010) Projeto de pesquisa: métodos qualitativo, quantitativo e misto (3 ed.). Porto Alegre: Artmed.

Dall'Agnol, C. M., \& Fernandes, F. S. (2007) Saúde e autocuidado entre catadores de lixo: vivências no trabalho em uma cooperativa de lixo reciclável. Rev Latino-am Enfermagem, 15 (número especial). Recuperado em 31 outubro, 2019, de http://www.scielo.br/pdf/rlae/v15nspe/pt_02.pdf

Davis, A. (2016) Mulheres, raça e classe. São Paulo: Boitempo.

Deslandes, S. F. (2012) O projeto de pesquisa como exercício científico e artesanato intelectual. In: Minayo, M. C. S., \& Gomes, S. (2012) Pesquisa social: teoria, método e criatividade. Rio de Janeiro: Vozes.

Fontes, V. (2010) O Brasil e o capital imperialismo - teoria e história. Rio de Janeiro: Fiocruz - EPSJV e UFRJ.

Freitas, L. F. S., Fonseca, I. F. (2012) Diagnóstico sobre catadores de resíduos sólidos. Brasília: Instituto de Pesquisa Econômica Aplicada - IPEA. Recuperado em 04 novembro, 2019, de 
http://www.ipea.gov.br/portal/images/stories/PDFs/relatoriopesquisa/120911_rel atorio_catadores_residuos.pdf

Froes, P. (2016) A $15 \mathrm{~km}$ do Planalto, a vida no maior lixão ativo da América Latina. Recuperado em $01 \quad$ julho, 2019, de http://www.bbc.com/portuguese/noticias/2016/03/160310_galeria_lixao_estrutur al_pf

Goes, E., Santos, E. M. (2014) Racismo, gênero e saúde no Brasil. $18^{\circ}$ REDOR, Universidade Federal Rural de Pernambuco, Recife-PE. Recuperado em 07 novembro, 2019. De http://www.ufpb.br/evento/index.php/18redor/18redor/paper/viewFile/1944/791.

Gonçalves, C. V., Malafaia, G., Castro, A. L. S., \& Veiga, B. G. A. (2012) A vida no lixo: um estudo de caso sobre os catadores de materiais recicláveis no município de Ipameri, GO. HOLOS, 29 (2), 238-250.

Goto, A. K., Souza, M. T. S., Júnior, J. V. L. (2009) Um estudo sobre o estresse em profissionais da área de logística da indústria automobilística. Psicologia política, 9 (18), 291-311.

Hirata, H. (2009). A precarização e a Divisão Internacional e Sexual do Trabalho. Sociologias. 11 (21), 24-41.

Hooks, B. (1995) Intelectuais negras. Revista Estudo Feministas. 3 (1), 464-478.

Junior, A. B. C., Ramos, N. F., Alves, C. M., Forcellini, F. A., \& Graciolli, O. D. (2013) Catadores de materiais recicláveis: análise das condições de trabalho e infraestrutura operacional no Sul, Sudeste e Nordeste do Brasil. Ciência \& Saúde Coletiva, 18 (11), 3115-3124.

Kleinman, A., Veena, D. A. S., Lock, M. (1996) Social suffering. Daedalus: Journal of the American Academy of Arts and Sciences, Winter, 125 (1).

Leandro, M. E. (2011) Teias da saúde: desigualdades de saúde, saúde das desigualdades. In: BRASIL. Saúde e direitos humanos. Ministério da Saúde. Fundação Oswaldo Cruz, Grupo Direitos Humanos e Saúde Helena Besserman, 7 (7), 18 - 33.

Lei n. 12.305 (2010) Dispõe sobre a Política Nacional de Resíduos Sólidos. Brasília. Recuperado em $31 \quad$ outubro 2019, de <http://www.planalto.gov.br/ccivil_03/_ato2007-2010/2010/lei/112305.htm

Mandel, E. (1982) O Capitalismo tardio. São Paulo: Abril Cultural.

Marcondes, M. M., Pinheiro, L., Queiroz, C., Querino, A., C., \& Valverde, D. (2013) Dôssie mulheres negras: retrato das condições de vida das mulheres negras no Brasil. Brasília: Instituto de Pesquisa Econômica Aplicada - IPEA, p. 1-168, Recuperado em 07 novembro, 2019, de http://ipea.gov.br/portal/images/stories/PDFs/livros/livros/livro_dossie_mulheres negras.pdf.

Marx, K., Engels, F. (1968) Manifesto comunista ( $3^{\text {a }}$ reimpressão). São Paulo: Boitempo.

Melo, H. P., Considera, C. M., Di Sabbato, A. (2007) Os afazeres domésticos contam. Economia e sociedade. 16 (3), 435-454.

Minayo, M. C. S. (2010) O desafio do conhecimento: pesquisa qualitativa em saúde $\left(14^{\mathrm{a}}\right.$ ed.). São Paulo: HUCITEC.

Minayo, M. C. S., \& Gomes, S. (2012) Pesquisa social: teoria, método e criatividade. Rio de Janeiro: Ed. Vozes.

Ministério do Trabalho e Emprego. (2013) CBO: Classificação Brasileira de Ocupações. 2013. Recuperado em 01 novembro, 2019, de http://www.mtecbo.gov.br/cbosite/pages/downloads.jsf

Oliveira, C. R. (1996) O trabalho antropológico: olhar, ouvir e escrever. Rev Antropologia, 39 (1), 13-37. 
Porto, M. F. S., Juncá, D. C. M., Gonçalves, R. S., \& Filhote, M. I. F. (2004) Lixo, trabalho e saúde: um estudo de caso com catadores em um aterro metropolitano no Rio de Janeiro, Brasil. Cad. Saúde Pública, 20 (6) 1503-1514.

Ribeiro, I. M., Nardi, H. C., \& Machado, P. S. (2012) Catadoras(es) de materiais recicláveis e as possíveis articulações entre trabalho precário e relações de gênero. Cadernos de Psicologia Social do Trabalho. 15 (2), 243-254.

Santos, G. O., \& Silva, L. F. F. (2009) Há dignidade no trabalho com o lixo? Considerações sobre o olhar do trabalhador. Revista Mal-estar e Subjetividade, 9 (2), 689-716.

Santos, S. M. R., Jesus, M. C. P., Mattos, L. R., Alves, M. J. M., Vicente, E. J. D., \& Jesus, P. B. R. (2012) Espiritualidade na avaliação da qualidade de vida dos catadores de materiais recicláveis: estudo transversal. On-line Brazilian Journal of Nursing, 11 (1). Recuperado em 04 novembro, 2019, de http://www.objnursing.uff.br/index.php/nursing/article/viewFile/3661/pdf_2

Siqueira, M. M., \& Moraes, M. S. (2009) Saúde coletiva, resíduos sólidos urbanos e os catadores de lixo. Ciência \& Saúde Coletiva, 14 (6), 2115-2122.

Vasconcelos, J. P. R., Guimarães, S. M. F., \& Zaneti, I. C. B. B. (2018) Condições de vida de catadores de resíduos sólidos recicláveis: revisão integrativa da literatura. Sustentabilidade em Debate, 9 (1), 187-197.

Zaneti, I. C. B. B. (2006) As sobras da modernidade: o sistema de gestão de resíduos em Porto Alegre. Rio Grande do Sul: CORAG.

Zaneti, I. C. B. B., Sá, L. M., Almeida, V. G. (2009) Insustentabilidade e produção de resíduos: a face oculta do sistema do capital. Sociedade e Estado. 24 (1), 173-192. 